OECD Taxation Working Papers No. 8

\title{
Non-Tax Compulsory \\ Payments as an Additional \\ Burden on Labour Income
}

Bert Brys 


\section{OECD CENTRE FOR TAX POLICY AND ADMINISTRATION}

\section{OECD TAXATION WORKING PAPERS SERIES}

This series is designed to make available to a wider readership selected studies drawing on the work of the OECD Centre for Tax Policy and Administration. Authorship is usually collective, but principal writers are named. The papers are generally available only in their original language (English or French) with a short summary available in the other.

The opinions expressed and arguments employed in these papers are the sole responsibility of the author(s) and do not necessarily reflect those of the OECD or of the governments of its member countries.

Comments on the series are welcome, and should be sent to either ctp.contact@oecd.org or the Centre for Tax Policy and Administration, 2, rue André Pascal, 75775 PARIS CEDEX 16, France.

Applications for permission to reproduce or translate all, or part of, this material should be sent to OECD Publishing, rights@oecd.org or by fax 33145249930.

Copyright OECD 2011 


\section{ABSTRACT \\ Non-tax compulsory payments as an additional burden on labour income}

In 23 of the 34 OECD member countries, it is compulsory for employers and/ or employees to make additional payments, in addition to taxes and social security contributions, which increase the overall burden on labour income. These non-tax compulsory payments, which are typically paid to privatelymanaged funds, will either increase the employer's labour costs or reduce the employee's net take-home pay in a similar way to taxes, although they do not necessarily have the same behavioural impact. This paper discusses the different non-tax compulsory payments levied in OECD member countries and calculates "compulsory payment indicators", which combine non-tax compulsory payments and taxes into an overall indicator of the burden of compulsory government regulation on labour income. The analysis shows that especially employers have to pay non-tax compulsory payments and that they have a considerable impact on the "tax wedge" rankings that are published in the OECD's Taxing Wages Report.

Keywords: non-tax compulsory payments, taxes, labour income, effective tax rates

\section{RÉSUMÉ}

\section{Les prélèvements obligatoires non fiscaux comme charge additionnelle sur les revenus du travail}

Dans 23 des 34 pays membres de l'OCDE, les employeurs et/ou leurs salariés sont tenus d'effectuer des paiements qui ne sont pas définis comme des impôts et cotisations de sécurité sociale et qui alourdissent la charge globale qui pèse sur les revenus du travail. Ces "prélèvements obligatoires non fiscaux", généralement effectués au profit de fonds à gestion privée, ont pour effet d'accroître les coûts de main-d'œuvre de l'employeur ou de réduire le revenu net disponible du salarié de la même manière que des impôts, bien qu'ils n'aient pas nécessairement les mêmes effets en termes de comportement. Ce document examine les différents prélèvements obligatoires non fiscaux en vigueur dans les pays membres de l'OCDE et calcule des "indicateurs de prélèvements obligatoires », qui combinent les impôts et les prélèvements obligatoires non fiscaux dans un indicateur d'ensemble de la charge sur les revenus du travail induite par la réglementation publique. L'analyse montre que ce sont surtout les employeurs qui sont soumis à des prélèvements obligatoires non fiscaux qui ont des répercussions très sensibles sur le classement du « coin fiscal » publié dans le rapport de l'OCDE intitulé «Les impôts sur les salaires ».

Mots clés: prélèvements obligatoires non fiscaux, impôts, revenus du travail, taux effectifs d'imposition 


\section{FOREWORD}

A previous version of this paper has been published as the Special Feature of the 2009 edition of the Taxing Wages Report; this paper provides updated results for 2010. The paper assumes that the reader is familiar with the OECD's Taxing Wages report and methodology. More information on Taxing Wages can be found at: www.oecd.org/ctp/taxingwages.

The paper has benefited from comments by Maurice Nettley, Stéphane Buydens and Alastair Thomas. The paper also draws on input from Delegates to Working Party No. 2 on Tax Policy Analysis and Tax Statistics of the Committee on Fiscal Affairs of the OECD. 


\title{
NON-TAX COMPULSORY PAYMENTS AS AN ADDITIONAL BURDEN ON LABOUR INCOME
}

\author{
Bert Brys ${ }^{1}$
}

\section{Introduction}

1. It is compulsory for employers in 22 OECD member countries to make payments for their employees which do not qualify as taxes and social security contributions. Also employees might have to pay additional contributions - mainly social insurance contributions - that are not taxes; this is the case in 10 OECD member countries. These "non-tax compulsory payments" (NTCPs) will either increase the employer's labour costs or reduce the employee's net take-home pay in a similar way to taxes. There are in total 23 OECD member countries where it is compulsory for employers and/or employees to make non-tax compulsory payments in relation to the employee's labour activity.

2. Non-tax compulsory payments are not modelled in Taxing Wages - the annual OECD Report which calculates the average and marginal tax burden on wage earnings in OECD member countries; for more information, see www.oecd.org/ctp/taxingwages - simply because they are not defined as taxes. However, some OECD member countries indicated an interest in measures that show the combined impact of taxes and non-tax compulsory payments. In addition to the well-known "tax wedges" which are presented in Taxing Wages, Working Party No. 2 of the OECD Committee of Fiscal Affairs therefore decided in 2010 to start calculating "compulsory payment wedges" which combine taxes, non-tax compulsory payments and benefits into overall "compulsory payment indicators". These new indicators will not be presented in the Taxing Wages Report. Instead, the compulsory payment indicators are included in the OECD online tax database www.oecd.org/ctp/taxdatabase.

3. Section 2 of this paper presents the main tax and non-tax compulsory payment definitions. Section 3 then discusses the reasons for calculating the compulsory payment indicators. Section 4 presents the compulsory payment indicators in more detail. Section 5 then provides an overview of the non-tax compulsory contributions which are levied on labour income in OECD member countries in 2010. Section 6 presents the empirical results; the analysis focuses on average and marginal compulsory payment wedges and rates as well as the change in total labour costs and net take-home pay as a result of NTCPs.

\section{Tax and non-tax compulsory payment definitions}

4. Taxing Wages models taxes (see the definition below) that are levied on wage earnings and which are generally applicable to taxpayers within at least one of the family types that are considered in the publication. These family types are distinguished by income level, marital status and number of children. Benefits that are generally available to such families are also modelled.

\footnotetext{
${ }^{1}$ Senior Tax Economist, Centre for Tax Policy and Administration, OECD. Contact Email: Bert.Brys@oecd.org.
} 
5. The OECD defines taxes as compulsory unrequited payments to general government (OECD Revenue Statistics (2010)).

- Taxes are compulsory in the sense that government imposes an obligation on taxpayers to pay a particular amount (in cash). Government sets the rules that determine the tax base and the rates that are applied to this tax base;

- Taxes are unrequited in the sense that benefits provided by government to taxpayers are not normally in proportion to the payments made by taxpayers. This means that there has to be a redistributive element - implying redistribution across households - in order for a payment to be considered a tax;

- Taxes are paid to general government, which is defined to include:

o the central administration and agencies whose operations are under its effective control;

○ state and local governments and their administrations;

○ social security funds/schemes;

$\circ$ autonomous government entities.

6. Compulsory social security contributions paid to general government are also treated as taxes. Being compulsory to general government they clearly resemble taxes. They may, however, differ from other taxes in that the receipt of social security benefits depends, in most countries, upon appropriate contributions having been made, although the size of the benefits is not necessarily related to the amount of the contributions, which implies that social security contributions are unrequited payments.

\section{Non-tax compulsory payments}

7. Non-tax compulsory payments (NTCPs) refer to the following compulsory payments made by employers or employees in connection with the employees' labour activity:

- $\quad$ Requited and unrequited compulsory payments to privately-managed funds, welfare agencies or social insurance schemes outside general government and to public enterprises.

The following bodies are considered to be outside general government:

- public enterprises, which are defined as “corporations, quasi-corporations ${ }^{2}$, non-profit institutions or unincorporated businesses that are subject to control by government units, with control over the enterprise being defined as the ability to determine general enterprise policy by choosing appropriate directors, if necessary";

- non-government bodies;

- welfare agencies and social insurance funds/schemes outside general government;

- trade unions or trade associations (even where such levies are compulsory).

2 Quasi-corporations are unincorporated enterprises that function as if they were corporations, and which have complete sets of accounts, including balance sheets. 
Compulsory payments to general government earmarked for bodies outside general government are also excluded if the government is simply acting in an agency capacity.

Compulsory contributions to social insurance schemes that are not institutions of general government, even though these schemes might have been imposed by government, private insurance companies, provident funds ${ }^{3}$, pension funds, friendly societies or other private saving schemes are therefore not social security contributions/taxes but NTCPs.

- $\quad$ Requited compulsory payments to general government made by employees or employers.

Payments are considered to be requited if the value of the benefits is (normally) in proportion to the payments (entitling individuals to receive the benefits) that are made. Compulsory payments to publicly-managed pension funds that entitle individuals to a pension that is an actuarially fair reflection of the contributions made are therefore NTCPs rather than taxes. However, this definition does not imply that requited payments have to accumulate at a market-based return.

8. Note that compulsory ${ }^{4}$ in the non-tax compulsory payment definition does not necessarily imply that government sets the rate that has to be paid. In the case of work-related private insurance, for instance, government might oblige the employer to insure its employees against work-related accidents with a private insurance company. The premium/rate of this insurance, however, could be set by the private insurance company.

\section{Borderline issues regarding the definition of taxes and NTCPs}

9. Although the dividing line between taxes and non-tax compulsory payments is clearly defined, in practice, however, it is not always straightforward to decide whether specific payments are taxes or NTCPs. For instance, compulsory pension savings that are controlled by general government and that accumulate on an individual account earning a market return or a rate that compensates for inflation would at first sight not be categorized as taxes. However, these payments might still be 'unrequited' and therefore classify as taxes instead of NTCPs (for example if these pension savings are not paid out if the taxpayer dies before (s)he reaches the pension age and the funds are then used to provide a minimum pension to all taxpayers that are insured).

10. The analysis in this paper (see Table S.6) suggests there are currently no compulsory requited payments to general government levied on labour income in OECD countries. This means that all types of compulsory payments to general government to some extent have a redistributional element, implying they are taxes rather than NTCPs. Note however that this conclusion is also the result of the typically broad interpretation of the term 'unrequited' in the tax definition.

3 Provident funds are arrangements under which the contributions of each employee and of the corresponding employer on his/her behalf are kept in a separate account earning interest and are withdrawable under specific circumstances.

4 Quasi-compulsory payments - payments that mainly arise by virtue of agreement with professional organisations and union organisations - are not included in the analysis. The same holds for payments that are not compulsory but are made by most employers within a country on a voluntary basis. These assumptions have an impact on the data comparability, especially with respect to non-tax pension contributions that are compulsory in some countries but not in other countries although many employers in the latter might pay similar contributions to privately-managed pension funds. The modelling of these 'non-tax non-compulsory payments' is left for future work. 
11. Borderline issues not only arise because of the 'unrequited' definition but complexity arises also with respect to the definition of 'general government'. Compulsory unrequited payments to funds that are largely controlled by general government, especially with respect to the most important characteristics of these payments, are typically classified as taxes and not as NTCPs, even though a strict interpretation of the 'general government' definition would result in the opposite conclusion.

\section{Standard personal income tax reliefs}

12. "Standard tax reliefs" are reliefs which are unrelated to actual expenditure incurred by the taxpayer and are automatically available to all taxpayers who satisfy the eligibility rules specified in the legislation. Standard tax reliefs are usually fixed amounts or fixed percentages of income and are typically the most important set of reliefs in the determination of the income tax paid by workers (see also section 6 in Part IV Methodology and Limitations of the Taxing Wages Report) ${ }^{5}$. Tax reliefs allowed for compulsory social security contributions are also considered as standard reliefs since they apply to all wage earners. In this case, the amount of tax relief is related to actual social security contributions paid by the employee thus in this respect this item deviates from the general definition of standard tax relief under which relief is unrelated to actual expenses incurred.

13. Contributions can be included as standard (personal income) tax reliefs in the Taxing Wages calculations whether or not they are taxes themselves. However, these tax reliefs do have to be generally available to taxpayers within at least one of the particular family types that are considered in the Report.

14. This implies that even though non-tax compulsory payments are not modelled in the tax equations that underlie the Taxing Wages results, these payments can be included as amounts that reduce the personal income tax burden if they qualify as standard personal income tax reliefs. Compulsory pension contributions to privately-managed funds, for instance, might be deductible from taxable personal income and would then qualify as a standard tax relief in Taxing Wages. ${ }^{6}$

\section{Why calculate compulsory payment indicators?}

15. Taxing Wages does not model NTCPs levied on wage earnings because these payments are not taxes. There are however good reasons to construct "compulsory payment indicators" that combine the burden of taxes and NTCPs:

5 Non-standard tax reliefs are not included in the Taxing Wages equations. Non-standard tax reliefs are reliefs which are wholly or partially determined by reference to actual expenses incurred. They are neither fixed amounts nor fixed percentages of income. Examples of non-standard tax reliefs include reliefs for interest on qualifying loans (e.g. for the purchase of a house), voluntary private insurance premiums, voluntary contributions to private pension schemes and charitable donations.

6 The tax treatment of compulsory pension payments to privately-managed funds differs across countries. In some countries, these non-tax pension payments cannot be deducted from the personal income tax base. However, the pension that will be received in the future might not be taxed again (TEE (taxed-exempt-exempt) treatment). In other countries, the non-tax compulsory pension payments can be deducted from the personal income tax base. However, the pension that will be received in the future might then be taxed under the personal income tax (EET (exempt-exempt-taxed) treatment). Because the Taxing Wages Report studies the current tax burden on labour income and does not model the tax burden on pensions that will be received in the future, it has been decided to model the deduction of the non-tax compulsory (pension) payments from the taxable personal income tax base if these payments qualify as standard tax reliefs. This approach ensures that the presented tax burden indicators in the Taxing Wages Report reflect the actual taxes paid as closely as possible. 
- One of the objectives of the OECD is to provide comparable data across OECD countries. Employee and employer NTCPs either increase the employer's total labour costs or decrease the employee's net-take home pay in a similar way to taxes. It therefore follows that taxes and NTCPs might be included in the same compulsory payment indicators.

- Employers' labour demand decisions will depend on total labour costs. Whether compulsory social security payments are paid to general government or to privately-managed social insurance funds, for instance, will often not be relevant. Also the employees' labour supply decisions might be independent of whether the social security/insurance contributions have to be paid to general government or to a privately-managed social insurance fund instead. This seems especially the case for compulsory unrequited payments to privately-managed health funds. ${ }^{7}$

- The inclusion of NTCPs and taxes in compulsory payment indicators might avoid discrete jumps in the tax burden which arise if contributions no longer have to be made to a public (private) fund but to a private (public) fund instead.

- These arguments in favour of compulsory payment indicators gain in importance if we expect to observe an increased shift of tax to NTCPs (or the other way around) in OECD member countries in the future. It is especially the shift of public pension savings towards pension savings through privately-managed funds that might be observed in the future as more and more countries implement (at least partially) a fully-funded pension system.

- On the other hand, however, some of the NTCPs, especially the contributions to privatelymanaged pension funds, are more likely to be requited than taxes. They might therefore have a different impact on taxpayers' behaviour than taxes. Of course, compulsory social security contributions differ in the extent to which the resulting benefit deviates from what is actuarially fair. However, it can be expected in general that privately-managed funds will provide a return that is more nearly actuarially fair. This argument then implies that taxes and NTCPs should not be combined in the same tax burden measure, as they may have different effects on behaviour. However, the separate calculation of tax burden indicators and compulsory payment indicators will make it possible for researchers to establish whether taxes and NTCPs do have different behavioural effects.

\section{Compulsory payment indicators}

16. This section introduces the "compulsory payment indicators" that are calculated in Section 6. The compulsory payment indicators include the taxes and the NTCPs that:

- $\quad$ have to be made by employees and employers as a result of the taxpayer's labour activity;

- that are generally applicable to taxpayers within at least one of the family types included in the Taxing Wages methodology; and

\footnotetext{
Given the strong resemblance with taxes, one might argue that compulsory 'unrequited' payments to privatelymanaged (health) funds - although these payments are not taxes because they are not paid to general government - could be included in the tax burden indicators presented in Taxing Wages. This line of reasoning has not been followed by Working Party No. 2 of the OECD Committee of Fiscal Affairs, which decided to include only 'taxes' into the Taxing Wages calculations and Report. Although the compulsory unrequited payments to privately-managed (health) funds are redistributive, it was argued that a deviation from the tax definition might lead to even more difficult/arbitrary choices about payments that should or should not be included in the tax burden measures that are presented in the Taxing Wages Report.
} 
- for which a representative rate can be constructed, if necessary.

17. The following indicators will be calculated (the symbol " $\Delta$ " means "change in"):

Average net personal compulsory payment rate $=$

income tax + employee SSC + employee NTCPS - cash benefits

gross wage earnings

Average compulsory payment wedge $=$

$\frac{\left(\begin{array}{c}\text { income tax }+ \text { employe SSC }+ \text { employer SSC }+ \\ \text { employee NTCPS + employer NTCPS - cash benefits }\end{array}\right)}{\text { gross wage earnings +employer SSC + payroll taxes +employer NTCPS }}$

Marginal net personal compulsory payment rate $=$

A(income tax + employee SSC + employee NTCPS - cash benefits)

$\Delta$ (gross wage earnings)

Marginal compulsory payment wedge $=$

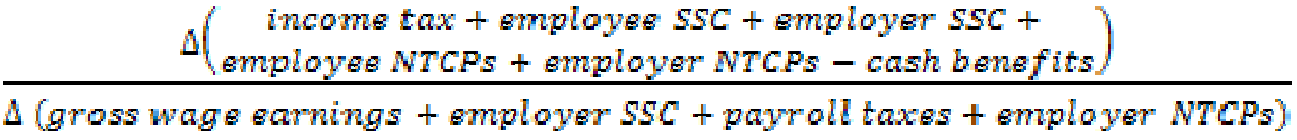

Adjusted net take-home pay $=$

gross wage earnings - taxes - employee SSC - employee NTCPS + cash benefits

Augmented total labour costs $=$

gross wage earnings + employer SSC + payroll taxes + employer NTCPS

18. The sum of total labour costs and employer NTCPs is denoted by the 'augmented total labour costs' in order to avoid confusion with the meaning of 'total labour costs' in the Taxing Wages Report. The net take-home pay net of employee NTCPs is denoted by 'adjusted net take-home pay'. Section 6 presents the decrease in the net take-home pay and the increase in the total labour costs, as a result of the NTCPs, in dollars with equal purchasing power in 2010.

19. The average/ marginal compulsory payment wedge measures the average/ marginal wedge between augmented total labour costs and adjusted net take-home pay as a result of taxes, SSC, NTCPs and benefits. The net personal average/ marginal compulsory payment rate measures the average/ marginal wedge between gross wage earnings and adjusted net take-home pay as a result of taxes, employee SSC, employee NTCPs and benefits. 


\section{Non-tax compulsory payments in OECD countries}

20. This section presents the details of the NTCPs that are levied in OECD countries in 2010 and that are modelled in the calculations underlying the results presented in this paper. In some cases, the NTCPs have not been included in the calculations. This is the case for work-related private insurance to cover accidents and occupational diseases. The details of these and other payments that are not included in the compulsory payment calculations are presented at the end of this section.

\section{NTCPs that are included in the calculations}

21. In Australia, employers are required to make contributions to the private pension plans of their employees under the Superannuation Guarantee scheme. While the Superannuation Guarantee scheme is mandated by the Australian Government, superannuation is provided through private superannuation funds subject to Government regulation. The Superannuation Guarantee requires employers to pay 9 per cent on top of each eligible employee's ordinary time earnings to a complying superannuation fund, where they earn AUD 450 or more in a month. ${ }^{8}$ However, employers may also choose to make contributions for workers earning less than this threshold. This threshold is not indexed. An upper earnings limit also applies. For each quarter, earnings beyond a threshold are not covered by the Superannuation Guarantee. This threshold is indexed to a measure of average earnings. In the 2009-10 tax year this threshold was AUD 40170 per quarter.

22. In Chile, it is compulsory for employees to make pension and unemployment insurance payments to privately-managed pension and insurance funds. The pension contributions amount to 10 per cent of gross earnings, with an upper limit of CLP 15078 874. Added to that is an amount that varies depending on the managing company that covers the management of each pension fund account and a disability insurance. The average cost is 2.2 per cent of income. The monthly unemployment insurance premium is 0.6 per cent of the employee's gross wage earnings, with an upper limit of CLP 22618311 . Employers make mandatory payments of 0.9 per cent of their employees' taxable income for an occupational accident and disease insurance policy (an additional higher rate of up to 3.4 per cent is also applied for activities of higher risk) subject to an upper earnings limit. For the majority of employees the payments are made to employers' associations of labour security which are private non-profit institutions. The remaining contributions are made to the Social Security Regularisation Unit (ISL). Although this latter organization is controlled by the government, the funds are invested on the private institutions market. In addition, employers make payments of 2.4 per cent of each employee's income ( 3 per cent for fixed-term contracts) to finance unemployment insurance. These funds are managed privately.

23. In Denmark, it is compulsory for employees who work at least 117 hours per month to pay a fixed contribution to a general Labour Market Supplementary Pension Scheme of DKK 1 080; this contribution also qualifies as a standard personal income tax relief. For workers who work less than 117 hours but not less than 78 hours, the contribution is DKK 720; for workers who work less than 78 hours but not less than 39 hours, the contribution is DKK 360. The employer makes a contribution that is double to the amount paid by the employee. The contributions are made to the employee's personal account within the Labour Market Supplementary Pension Scheme. These fixed employee and employer contributions are therefore NTCPs.

Ordinary time earnings is the total of the employee's earnings in respect of ordinary hours of work, including over-award payments, shift loading or commission but not including most overtime or lump-sum payments made on termination of employment in lieu of unused annual leave, long service leave, or sick leave. See Superannuation Guarantee Ruling SGR 2010/2 for further details: http://aw.ato.gov.au/atolaw/view.htm. 
24. At the beginning of 2009 Estonia had an NTCP in the form of II pillar pension contributions. These represented compulsory payments to private funds for employees born in 1983 or after at a rate of 2 per cent of earnings. They could also at the same time be paid on a voluntary basis by older workers. At the end of May 2009, these payments became wholly voluntary and remained so throughout the remainder of 2009 and all of 2010. These contributions are therefore not included in the equations underlying the NTCP results.

25. In Iceland, employees are required to make contributions to a private pension fund, which is generally linked to a labour union or another employee association. The employee contribution is generally 4 per cent of wages. Employers are also required to contribute 8 per cent of the employees' wages. Both contributions are deductible from income before tax. Employees and employers may make larger contributions, but the employee deduction is limited to a maximum of 8 per cent of gross wages. An optional additional payment from employees of up to 4 per cent of wages is also tax deductible and goes into an individual retirement account. The employer may match the employee's optional additional payments, but only extra contributions up to 2 per cent of wages are deductible from the employer's taxable income.

26. In Israel, non-tax compulsory pension contributions apply to paid employees - males aged above 21 and females aged over 20 - who have been working for at least 6 months with the same employer or they have held an account with a pension fund for 3 months. Foreign workers are excluded. The contributions are based on a percentage of the employee's gross wage subject to an upper limit. In 2009, employee contributions were 1.66 per cent of salary and employer contributions 3.34 per cent subject to an earnings limit of ILS 95136. In 2010 employer contributions are 2.5 per cent of salary and employer contributions 5 per cent subject to an earnings limit of ILS 96180.

27. The Trattamento di Fine Rapporte (TFR) in Italy is a severance pay. This postponed wage is paid to the employee at the end of the working relationship. Contributions to the TFR consist of the yearly employer contributions equal to 7.4074 per cent (1/13.5) of the annual gross wage earnings of the employee in 2010. These payments accumulate at a rate that is linked to the inflation rate. This total amount will be paid to the employee at the end of the labour contract. In 1993, a reform was introduced that attempted to stimulate the sector of private pensions in Italy. Workers could now ask their employer to pay the TFR contribution to a private pension fund and save for an additional pension instead of a severance pay. As from 2007, the TFR contribution will be managed either by the company or by a government social security institution (depending on the size of the firm); also the pension fund can be either private or public. These contributions are requited payments and are therefore modelled as NTCPs instead of taxes. ${ }^{9}$

28. In Luxembourg, employers must make payments to the Employers' Mutual Insurance Scheme. This scheme provides insurance for employers against the financial cost of continued payment of salaries or wages to workers who become incapacitated. (Employers are required to pay the remuneration of an employee who is unable to work until the end of the month in which the seventy-seventh day of incapacitation occurs within a reference period of twelve successive calendar months). The Scheme is administered by a Board of Directors which is mainly composed of employer representatives (Chamber of Commerce, Chamber of Trade, Chamber of Agriculture and Federation of Independent Intellectual Workers). Employer contributions depend on the rate of "financial absenteeism" within the company, and range from 0.88 to 2.01 per cent. A representative rate of 1.36 per cent is used in the NTCP calculations.

9 The tax treatment of the severance pay or pension that the employee receives at the end of the working relationship is not considered in the compulsory payments indicators or Taxing Wages. 
29. All employees and retirees in Luxembourg (with the exception of public officials) have to belong to the Chamber of Employees ("Chambre des salaries") regardless of their nationality or place of residence. Annual dues are automatically withheld by the employer or by the Pension Insurance and allow the chamber to carry out its various activities and missions. The contributions are fixed for 2009 and 2010 at EUR 31 for every employee who earns a gross monthly salary of EUR 300 or more - this contribution is included in the calculations, EUR 10 for every other employee and EUR 4 per apprentice. This non-tax compulsory employee payment is withheld by the employers jointly with the withholding tax on salaries.

30. In Mexico, employees and employers must make discharge and old age insurance contributions to a privately-managed fund, while employers are also required to make retirement pension contributions to a privately-managed fund. Employers must additionally make contributions to the INFONAVIT housing fund, a government-owned home loan provider. The base for all these payments is the worker's 'base salary", with a ceiling equivalent to 25 times the minimum wage applicable in Mexico City (MXN 524323 in 2010). The "base salary" includes cash payments of daily fees, premiums, non-cash benefits and any other fringe benefits (subject to some exceptions). The employee discharge and old age insurance rate is 1.125 per cent, and is not deductible. The employer discharge and old age insurance rate is 3.15 per cent, while the retirement pension rate is 2 per cent, and the housing fund rate is 5 per cent. These payments are deductible for the employer.

31. In The Netherlands compulsory contributions under collective labour agreements are paid by employees and employers to privately-managed pension funds (i.e. the second pillar). All company sectors ${ }^{10}$ are obliged to have a pension arrangement for their employees. Capital will be built up and will be invested to create an acceptable rate of return on capital. The pension premiums differ per company. On average employees working in the market sector pay a pension premium in 2010 of 3.76 per cent ${ }^{11}$ of gross earnings net of the pension franchise of EUR 12952 in 2010. These pension premiums are not considered as SSC but as employee NTCPs instead. The pension franchise is built in the pension scheme to prevent that an employee whose wage is too low to obtain a second pillar pension (and so receives only the first pillar pension) would have to pay pension premiums in the second pillar. The employee does not have to pay personal income tax on the pension premiums that are paid but the pension will be taxed when the employee retires. The premiums of the employee qualify as a standard tax relief. On average employers in the market sector pay an pension premium in 2010 of 17.10 per cent of gross earnings of their employees exclusive the pension-franchise of EUR 12952 in 2010. The compulsory pension premiums of employers to privately-managed funds are NTCPs.

32. For basic health insurance, each adult in the Netherlands pays an average amount of EUR 1064 a year to a privately-managed health insurance company. Employees might obtain compensation for this nominal contribution, depending on the family situation and taxable income. This is called the health care benefit. This benefit and the basic insurance premium are included in the NTCP calculations. The health care benefit compensates for the basic insurance premium of on average EUR 1064 . Also 6.9 per cent of gross earnings net of employees' pension premiums and unemployment social security contributions is paid for health care up to a maximum of net earnings of EUR 32 369. For the last contribution, an employee receives mandatory compensation of his employer for the same amount. This amount is included

10 Very small companies do not have pension arrangements for their employees. If a company offers a pension arrangement to one of its employees, it has to offer the same arrangement to all of its employees. Nearly all SME's (approximately 95 per cent) have pension arrangements for their employees.

11 Final information regarding the pension premium contributions for employees and employers in Sectors C$\mathrm{K}$ (ISIC Rev. 3.1), as a percentage of average earnings, becomes definitive only after three years. This implies that currently only definitive information regarding the contribution rates for the year 2006 and prior years is available. An estimated non-tax compulsory employees' and employers' pension contribution rate for 2010 has been used in the 2010 NTCP calculations. 
in the taxpayer's taxable income. This amount is included in the Taxing Wages calculations in order to calculate the taxpayer's personal income tax liabilities. The income dependent health contribution itself, however, is not modelled (either as an employee or employer SSC) in Taxing Wages. Instead it is modelled as a NTCP from the employer to a publicly-managed health insurance fund. The spending of this fund mainly compensates private insurance companies for their (public) obligation to insure individuals with a high health risk.

33. Since January 2006, companies in Norway must have an occupational pension scheme for their employees. It is, however, permitted to exclude employees under the age of 20 and those in part-time employment of less than 20 per cent of a full-time position. Employers can have either a defined contribution or a defined benefit pension scheme. Defined contribution schemes are offered by banks, life insurance companies, pension funds and companies that manage securities funds. Defined benefit schemes are offered by life insurance companies and pension funds. Employers pay contributions of at least 2 per cent of the employee's earnings between $1 \mathrm{G}$ and $12 \mathrm{G}$ ( $\mathrm{G}$ is the National Insurance basic amount and the average for 2010 was NOK 74 721) to the pension scheme. Employers are also obliged to cover the costs of administering the pension scheme. In addition to the pension contribution, the pension scheme also contains an insurance element that ensures that employees continue to earn pension entitlements in the event of disability. Employees may be required to also contribute to their own pension; these contributions are however not included in the NTCP calculations.

34. Individuals in Poland that are subject to social insurance (i.e. due to employment) are obliged to pay pension contributions. Half of these contributions are paid by the employee (9.76 per cent of gross wage earnings) and are deductible from taxable personal income. The equivalent amount is paid by the employer. Those amounts (19.52 per cent of gross wage earnings) are collected by the Social Insurance Institution (Zaklad Ubezpieczen Spolecznych - ZUS), which is a government agency. The earnings ceiling for contributions is PLN 94380 in 2010.

35. Part of the pension contributions (62.60 per cent, hence about 12.22 per cent of gross wage earnings) is controlled by ZUS. The amount of paid pension contributions is filed (recorded) on an individual account for each insured person by ZUS. These pension contributions do not accumulate at market conform rates but increase at a return that reflects the increase in prices of goods and services (annual indexation). These savings are not paid out if the taxpayer dies before reaching the pension age; these funds are then used to finance the minimum amount of pension that is guaranteed by ZUS. This redistributional element implies that these payments are taxes.

36. The other part of the contribution (37.40 per cent, hence about 7.3 per cent of gross wage earnings) is transferred by ZUS to a privately-managed pension fund, which is called an "open pension fund (OPF)". These contributions are NTCPs. The pension contributions controlled by OPF do accumulate at market conform rates. The pension savings are paid out if the taxpayer dies before reaching the pension age (i.e. as long as the taxpayer is a member of OPF). Capital accumulated by the taxpayer in OPF is transferred to the Pension Institution (ZUS) when the taxpayer reaches the pension age (65 years for men and 60 for women). The insured person can choose the private pension fund through which (s)he saves for a pension. If the individual does not make a choice between one of the privately-managed funds that are currently on the market in Poland, ZUS will choose instead. ${ }^{12}$

12 There is a small group of the insured that are not obliged to save for a pension through an OPF. These are persons that are born before 1949. Also persons that are born between 1949 and 1968 could have chosen not to enter the new pension system. They pay their contributions exclusively to ZUS and they will receive their pension based only on the indexed savings filed (recorded) by ZUS. 
37. Since January 2005, the Slovak Republic has introduced a privately-managed fully-funded pension pillar. From 2008 onward, employees that enter the labour market have the option to either join the private pension scheme or not. If the employee joins the scheme, the employer will pay contributions of 9 per cent of earnings to the privately-managed pension fund. The employer will also pay contributions of 5 per cent of earnings to the Social Insurance Agency within general government. If the employee decides not to join the private pension scheme, the employer will pay contributions of 14 per cent of earnings to the Social Insurance Agency. As employers are not obliged to pay the 9 per cent of earnings to the general government (depending on whether the employee decides to participate in the privately-managed fully funded pension scheme or not), these payments are not considered to be taxes. Because these payments are compulsory - in fact, most employees (60 per cent) participate in the private pension scheme - these pension contributions are considered to be NTCPs instead. The non-tax compulsory pension payments are levied on the same tax base as the pension social security contributions.

38. Employers in the Slovak Republic are obliged to create Social Funds (SFs) as a social policy tool for their employees. The compulsory contribution rate to the SF ranges from 0.6 to 1.0 per cent of all gross wages payable to employees during the calendar year. The exact rate depends on the employer's profit in the previous year. All resources in the SFs have to be distributed to the employees. Employers have to provide the employees with a benefit from the SFs in cash or in kind with respect to:

- catering for the employees beyond the scope specified in the special regulations;

- $\quad$ travel to work and back;

- participation in cultural and sports events;

- recreation and services utilized to regenerate the labour force;

- healthcare;

- $\quad$ social aid and money loans;

- $\quad$ supplementary pension savings excluding the contribution to the supplementary pension savings for which the employer is obliged to pay pursuant to a special regulation;

- further implementation of the corporate social policy in the area of employee care.

39. These contributions to SFs increase total labour costs for employers in the Slovak Republic. There is no financial link with general government because SFs are managed by employers, so these compulsory payments can be qualified as NTCPs. The calculations assume a rate of 0.6 per cent.

40. In Sweden, employees must pay a burial fee to the Church of Sweden. This fee is levied as an additional 0.22 per cent - this rate is a weighted average across municipalities - on top of the local tax rate. If the taxpayer is a member of the Church of Sweden then this burial fee is included in the higher membership fee. In Stockholm and Tranås, however, the fee has to be paid to the municipality who is responsible for the burials.

The total amount of indexed savings filed (recorded) by ZUS and capital accumulated in OPF are pooled by the Pension Institution when the taxpayer reaches his/her pension age; the total amount of funds are used to calculate the value of the monthly pension. It is calculated by dividing the amount of pooled savings by the average length of life (after the pension age). A minimum monthly pension is guaranteed (PLN 706,29 since March 1, 2010). 
41. In Switzerland the following non-tax compulsory payments have to be paid:

- Contributions to the second pillar of the pension system (occupational pension funds): Occupational pension funds are mandatory for salaried persons earning at least CHF 20880 annually. Old age insurance is based on individual savings. The savings assets accumulated by the insured person on his individual savings account over the years serve to finance the old age pension. The constituted capital is converted into an annual old age pension on the basis of a conversion factor. Contribution rates depend on the occupation and the pension fund. An estimated representative rate amounts to $7.65 \%$ for employees and $9.75 \%$ for employers in 2010.

- Health insurance is compulsory for all persons domiciled in Switzerland. Every family member is insured individually, regardless of age. Health insurance contributions are lump sum contributions per capita depending on age, sex, canton of residence and insurer. A representative rate has to be estimated; for 2010 it amounts to CHF 4213 for adults and CHF 1008 for children per year.

- Family allowance: Employers have to make family allowance contributions. The contribution rates differ among cantons and family contribution funds. A representative rate has to be estimated, for 2010 it amounts to $1.2 \%$.

- Accident insurance: Accident insurance is compulsory for every employee. Employees are automatically insured by their employer, whereas the employers are more or less automatically assigned to a particular insurance company depending on their branch of trade. The risk and associated costs of the respective business activity determines the insurance premiums.

\section{Employer work-related private insurance to cover accidents and occupational diseases are not modelled}

42. In 12 OECD countries (Australia, Belgium, Chile, the Czech Republic, Denmark, Germany, New Zealand $^{13}$, Poland, Portugal, Spain, Switzerland and the United States), it is compulsory for employers to insure their employees against work-related accidents and occupational diseases with a private insurance company (see Table S.6). Governments typically do not impose a premium/rate that has to be paid. Instead, the premium/rate that insurance companies charge typically depends on the risk characteristics of the insured jobs involved.

43. These insurance premiums/rates are NTCPs. However, in order to present data that is comparable across countries, NTCPs have been included in the compulsory payment calculations and indicators only if they are generally applicable to taxpayers within at least one of the family types that are included in the Report or if these payments are representative of the actual payments that these taxpayers or their employers make on average.

44. An ideal representative insurance rate would be obtained by calculating a weighted average premium/rate where the weights depend on the share of workers in the total labour force (in sectors C-K in ISIC Rev. 3.1 or sectors B-N in ISIC Rev. 4) whose employer pays that particular premium/rate. This requires the availability of detailed information on the labour force (number and types of insured workers within each country) and the work-related insurance premium/rate that their employer pays. Note that this premium/rate would then depend on the country's actual industry structure.

13 As part of New Zealand's broader Accident Insurance Scheme, both employer and employee contributions must be made to the Accident Compensation Corporation, a wholly state owned company. 
45. In practice, most OECD countries face difficulties in calculating this representative insurance premium/rate. In order to ensure data comparability across OECD countries, it was therefore decided not to include compulsory work-related private insurance to cover accidents and occupational diseases in the NTCP calculations. The overview table (Table S.6) included at the end of the text does however provide information on the countries that have compulsory work-related private insurance to cover accidents and occupational diseases.

\section{Other NTCPs that are not modelled}

46. In Austria, a new program was introduced in 2001 that replaced the system of severance payments ("Abfertigung") which the employer had to pay when an employee was fired or retired. As of 1 January 2001, employers are required to pay 1.53 per cent of gross wages to the Social Health Security Fund ("Krankenkassen") for those whose employment started after that date. It can also apply to taxpayers who started working before 2001 if the employer and employee opt to participate in the new program. The Social Health Security Fund then transfers the contributions to a privately-managed fund, which is now responsible to distribute the severance payments in case the employee is fired or retires. Because these contributions are not generally applicable to all taxpayers - taxpayers who started working before 2001 are not obliged to enter the new system - these NTCPs are not included in the calculations.

47. In Hungary, workers are required to either join a private pension fund, or contribute to the public social security scheme. Either way they are required to make the same total payment of 9.5 per cent of wages. For taxpayers choosing to join a private pension scheme, 8 per cent of wages is paid to the pension fund while the remaining 1.5 per cent goes to the public social security scheme. For non-members the entire 9.5 per cent goes to the public scheme. Neither payment is deductible against personal income tax. The Taxing Wages publication assumes workers are not members of a private pension fund and therefore includes the 9.5 per cent as social security contributions (taxes) in the Taxing Wages calculations. As of 1 November 2010, both members and non-members of a private pension scheme $\left(2^{\text {nd }}\right.$ pillar) are obliged to pay the 9.5 per cent compulsory pension contribution to the public social security system; it is no longer mandatory to make contributions to the private pension scheme.

\section{Other payments that do not qualify as NTCPs}

48. In Korea, it is compulsory for employers to pay an additional payment or pension to an employee who is fired or retires, but it is not compulsory for employers to accumulate funds to pay for these future pensions or severance payments. As a result, any contributions that employers may make during the period that the employee is hired - for instance to a privately-managed pension fund or an internal fund within the firm - in order to pay for the severance payments or pension at the end of the working relationship are not modelled as NTCPs.

49. Employers in New Zealand will also be required to make KiwiSaver payments where the employee has joined the KiwiSaver scheme. KiwiSaver is a Government initiated retirement savings scheme. Given that KiwiSaver is voluntary for employees to join, the payments are not considered to be NTCPs. Where an employee is a member of KiwiSaver, and is contributing to the scheme, compulsory employer contributions are 2 per cent of an employee's gross wage. However, employers are exempt from contributions if they are already paying into another eligible registered superannuation scheme for an employee, the employee is under 18 or over 65 , or the employee is not contributing themselves (e.g. on a payments holiday). KiwiSaver is administered directly through the tax system. 


\section{Empirical findings}

50. There are 23 OECD member countries that have NTCPs that are levied on wage earnings. 14 OECD countries (Australia, Chile, Denmark, Iceland, Israel, Italy, Luxembourg, Mexico, the Netherlands, Norway, Poland, the Slovak Republic, Sweden and Switzerland) levy NTCPs that are generally applicable to taxpayers; these NTCPs have been included in the calculations underlying the compulsory payment indicators. There are also 12 OECD countries (Australia, Belgium, Chile, the Czech Republic, Denmark, Germany, New Zealand, Poland, Portugal, Spain, Switzerland and the United States) where it is compulsory for employers to insure their employees against work-related accidents and occupational diseases with a private insurance company (Table S.6). These NTCPs have not been included in the compulsory payment indicators as most of these countries face difficulties in calculating a representative insurance premium/rate. Also the NTCPs in Austria, Hungary and the employee contributions to the Accident Compensation Corporation in New Zealand have not been modelled.

51. Table S.1 and S.3 present, respectively, average and marginal compulsory payment wedges by family-type and wage level as a percentage of augmented total labour costs in 2010. Table S.2 and S.4 present corresponding figures for average and marginal net personal compulsory payment rates respectively.

52. Figure S.1 compares average compulsory payment wedges and average tax wedges for single taxpayers without children at average earnings in 2010. Figure S.2 compares marginal compulsory payment wedges and marginal tax wedges for single taxpayers without children at average earnings in 2010 .

53. Note that the average and marginal compulsory payment wedges and tax wedges included in Figures S.1 and S.2 are not additive because of the differences in the denominators of the different ratios. The tax wedge shows all taxes paid net of benefits received as a percentage of total labour costs. The compulsory payment wedge shows all taxes and non-tax compulsory payments net of benefits received as a percentage of 'augmented' total labour costs, which equals total labour costs plus the employer NTCPs. ${ }^{14}$

54. Figure S.1 shows that, for single taxpayers at average earnings without children, the impact of NTCPs on average wedges is the strongest in Switzerland, Chile, the Netherlands, Iceland, Mexico, Australia, Poland, Israel, the Slovak Republic and Italy. For this family type, Figure S.2 shows that the impact of NTCPs on the marginal wedges is the strongest in Chile, Switzerland, the Netherlands, Mexico and Iceland. These Figures also indicate that the inclusion of NTCPs has a considerable impact on the respective country rankings.

55. Table S.5 presents the increase in total labour costs and the reduction in net take-home pay as a result of NTCPs by family-type and wage level in 2010. The amounts are expressed in US dollars using PPP in order to ensure comparability. The highest amount of employer NTCPs has to be paid in (in decreasing order):

- The Netherlands;

- $\quad$ Switzerland;

- Australia;

- Italy;

- Iceland;

14 This comparison issue could be resolved by dividing the non-tax compulsory payments by total labour costs. 
- The Slovak Republic;

- Israel;

- Mexico;

- Norway;

- Luxembourg;

- Poland;

- Chile;

- Denmark.

The highest amount of employee NTCPs has to be paid in (in decreasing order); the amounts are very small in Mexico, Denmark, Sweden and Luxembourg:

- $\quad$ Switzerland;

- The Netherlands;

- Chile;

- Iceland;

- Poland;

- Israel;

- Mexico;

- Denmark;

- Sweden;

- Luxembourg.

56. NTCPs are relatively small in Denmark, Luxembourg and Sweden. The other countries levy larger amounts of NTCPs (combined employee and employer NTCPs exceeding US dollars 1000 using PPP for most family types). This is the case for Australia, Chile, Iceland, Israel, Italy, Mexico, the Netherlands, Norway, Poland, the Slovak Republic and Switzerland. In all of these countries, the NTCPs are mainly pension contributions.

57. The results also show that NTCPs are mostly paid by employers - thereby increasing total labour costs - and not by employees. ${ }^{15}$ Only in Chile, Iceland, Israel, the Netherlands, Poland and Switzerland do employees pay a considerable amount of non-tax compulsory payments.

58. Finally, the analysis suggests there are currently no compulsory requited payments to general government levied on labour income in OECD countries. This means that all types of compulsory payments to general government to some extent have a redistributional element, implying they are taxes rather than NTCPs.

15 This conclusion ignores the possible incidence effects; employer NTCPs could be borne by employees through lower gross wage earnings. 
Table S.1. Average compulsory payment wedge

by family-type and wage level (as \% of augmented total labour costs), 2010

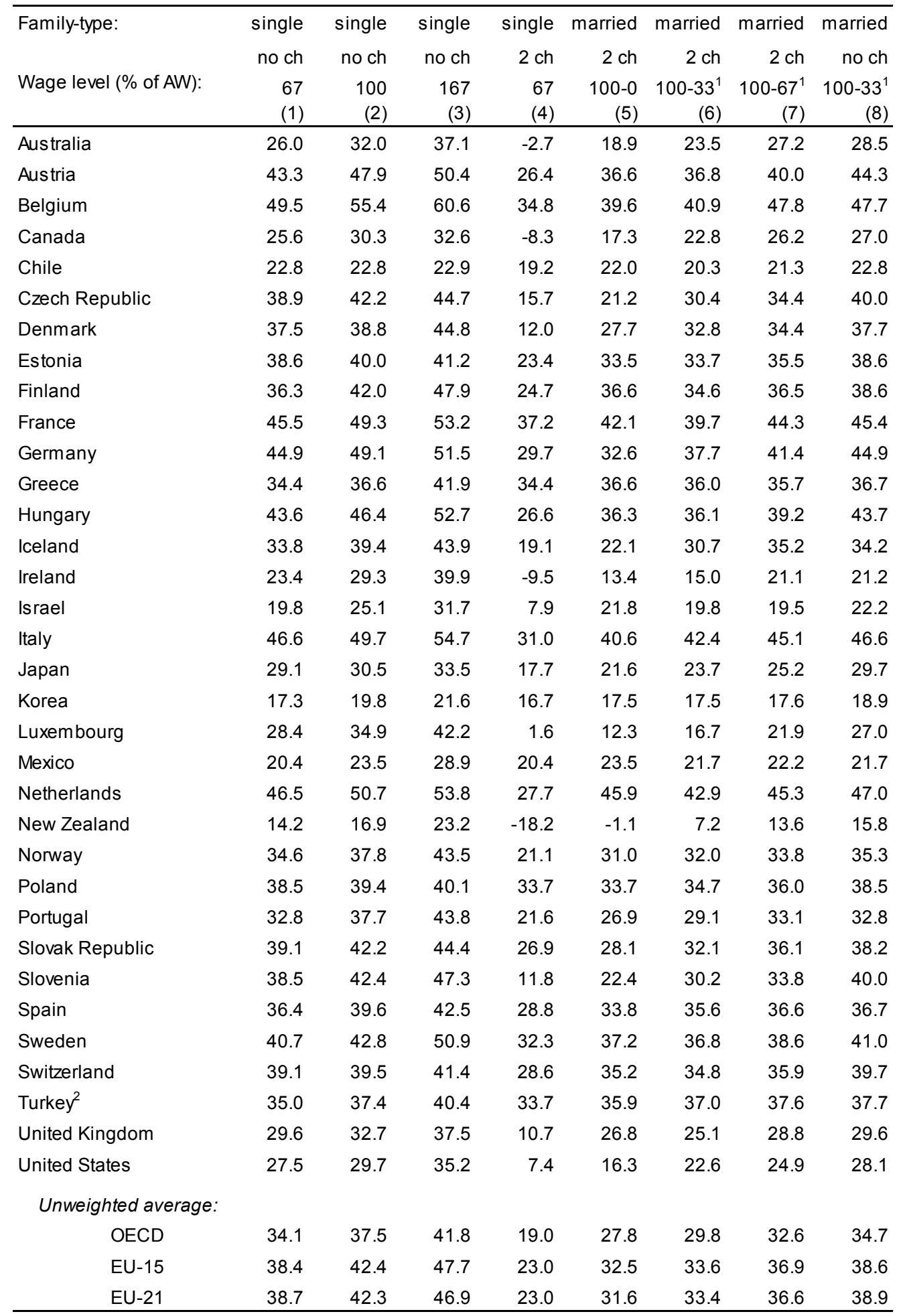

Note $:$ ch $=$ children.

1. Tw o-earner family.

2. Turkey wage figures are based on the old definition of average production w orker (Sector D in ISIC Rev.3). 
Figure S.1. Average compulsory payment wedge and average tax wedge for single taxpayers without children at average earnings, $2010^{1}$

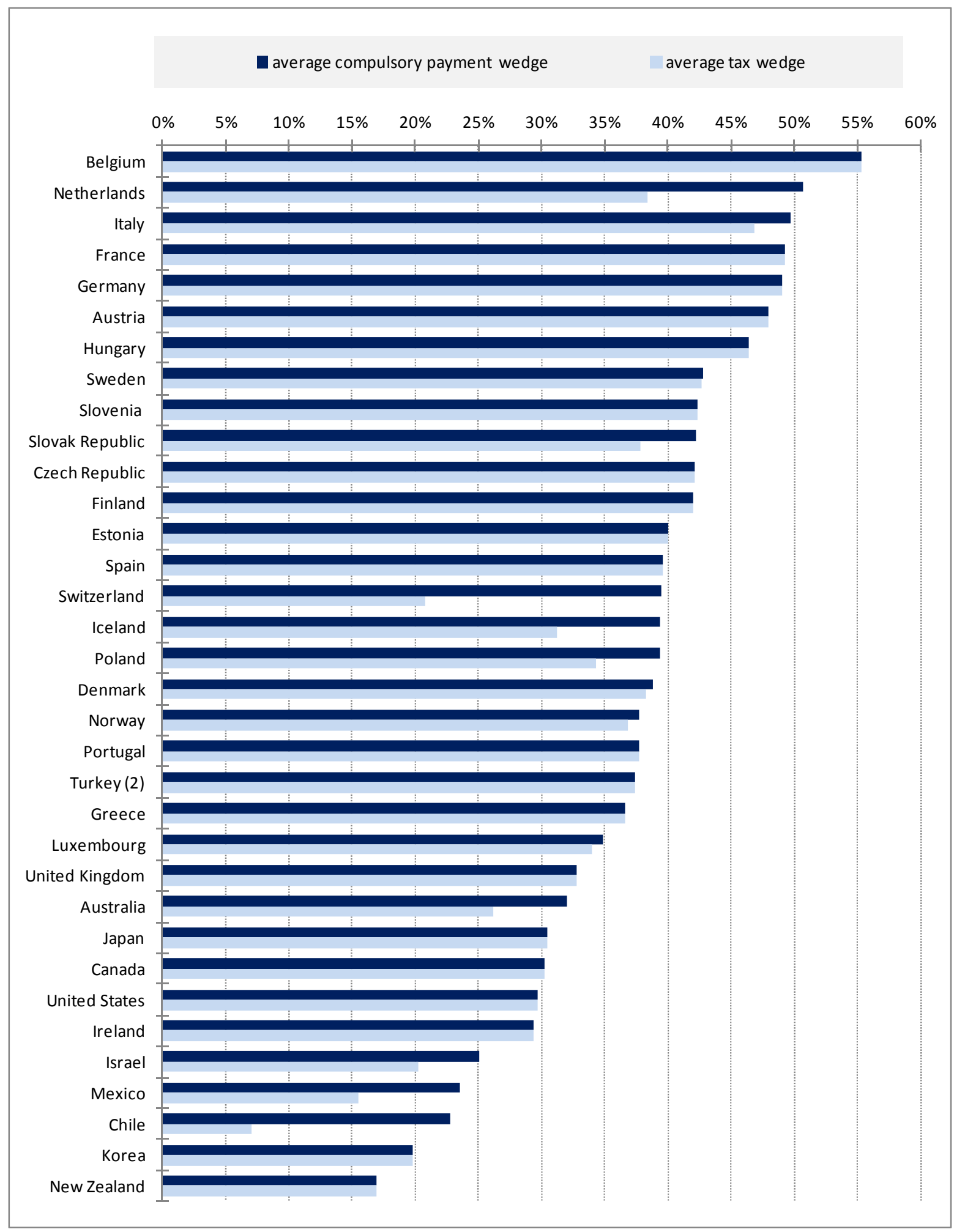

1. Countries are ranked by decreasing average compulsory payment wedge.

2. Turkey wage figures are based on the old definition of average production worker (Sector D in ISIC Rev.3). 
Table S.2. Average net personal compulsory payment rate

by family-type and wage level (as \% of gross wage earnings), 2010

\begin{tabular}{|c|c|c|c|c|c|c|c|c|}
\hline Family-type: & $\begin{array}{l}\text { single } \\
\text { no ch }\end{array}$ & $\begin{array}{l}\text { single } \\
\text { no ch }\end{array}$ & $\begin{array}{l}\text { single } \\
\text { no ch }\end{array}$ & $\begin{array}{r}\text { single } \\
2 \mathrm{ch}\end{array}$ & $\begin{array}{r}\text { married } \\
2 \mathrm{ch}\end{array}$ & $\begin{array}{r}\text { married } \\
2 \mathrm{ch}\end{array}$ & $\begin{array}{r}\text { married } \\
2 \mathrm{ch}\end{array}$ & $\begin{array}{r}\text { married } \\
\text { no ch }\end{array}$ \\
\hline Wage level (\% of AW): & $\begin{array}{l}67 \\
(1) \\
\end{array}$ & $\begin{array}{r}100 \\
(2) \\
\end{array}$ & $\begin{array}{r}167 \\
(3) \\
\end{array}$ & $\begin{array}{l}67 \\
(4) \\
\end{array}$ & $\begin{array}{r}100-0 \\
(5) \\
\end{array}$ & $\begin{array}{r}100-33^{1} \\
(6) \\
\end{array}$ & $\begin{array}{r}100-67^{1} \\
(7) \\
\end{array}$ & $\begin{array}{r}100-33^{1} \\
(8) \\
\end{array}$ \\
\hline Australia & 14.7 & 21.6 & 27.5 & -18.3 & 6.6 & 11.8 & 16.1 & 17.6 \\
\hline Austria & 26.8 & 32.7 & 37.4 & 5.0 & 18.1 & 18.4 & 22.6 & 28.1 \\
\hline Belgium & 35.4 & 42.1 & 49.0 & 16.7 & 21.6 & 26.2 & 32.7 & 34.7 \\
\hline Canada & 17.2 & 22.2 & 26.5 & -20.7 & 7.7 & 14.0 & 17.7 & 18.7 \\
\hline Chile & 20.9 & 20.9 & 21.0 & 17.2 & 20.1 & 18.4 & 19.4 & 20.9 \\
\hline Czech Republic & 18.2 & 22.5 & 25.9 & -12.9 & -5.5 & 6.7 & 12.0 & 19.6 \\
\hline Denmark & 37.0 & 38.5 & 44.6 & 11.3 & 27.3 & 32.2 & 33.9 & 37.1 \\
\hline Estonia & 17.4 & 19.4 & 20.9 & -2.9 & 10.7 & 10.9 & 13.4 & 17.4 \\
\hline Finland & 22.1 & 29.1 & 36.3 & 7.9 & 22.5 & 20.0 & 22.3 & 24.9 \\
\hline France & 25.9 & 27.8 & 33.3 & 14.6 & 17.5 & 18.1 & 22.1 & 25.9 \\
\hline Germany & 34.2 & 39.2 & 43.8 & 16.1 & 19.6 & 25.7 & 30.1 & 34.2 \\
\hline Greece & 16.0 & 18.8 & 25.7 & 16.0 & 18.8 & 18.1 & 17.7 & 19.0 \\
\hline Hungary & 27.5 & 31.2 & 39.2 & 5.7 & 18.1 & 17.8 & 21.9 & 27.6 \\
\hline Iceland & 22.7 & 29.3 & 34.6 & 5.6 & 9.1 & 19.1 & 24.4 & 23.2 \\
\hline Ireland & 15.1 & 21.8 & 33.5 & -21.3 & 4.1 & 6.3 & 12.6 & 13.1 \\
\hline Israel & 12.3 & 18.5 & 26.7 & -0.6 & 15.0 & 12.8 & 12.3 & 15.4 \\
\hline Italy & 25.5 & 29.8 & 36.8 & 3.8 & 17.1 & 19.7 & 23.5 & 25.5 \\
\hline Japan & 19.3 & 20.8 & 24.7 & 6.3 & 10.7 & 13.1 & 14.8 & 19.9 \\
\hline Korea & 9.1 & 11.9 & 14.9 & 8.4 & 9.4 & 9.4 & 9.5 & 10.9 \\
\hline Luxembourg & 19.2 & 26.5 & 34.7 & -11.0 & 1.1 & 6.0 & 11.9 & 17.6 \\
\hline Mexico & 1.3 & 6.7 & 14.5 & 1.3 & 6.7 & 2.8 & 4.5 & 2.8 \\
\hline Netherlands & 32.5 & 37.0 & 42.6 & 8.7 & 30.9 & 28.5 & 30.4 & 33.7 \\
\hline New Zealand & 14.2 & 16.9 & 23.2 & -18.2 & -1.1 & 7.2 & 13.6 & 15.8 \\
\hline Norway & 25.2 & 28.7 & 35.2 & 9.8 & 21.0 & 22.2 & 24.3 & 26.0 \\
\hline Poland & 27.1 & 28.2 & 29.1 & 21.5 & 21.5 & 22.7 & 24.2 & 27.1 \\
\hline Portugal & 16.9 & 22.9 & 30.4 & 3.0 & 9.5 & 12.3 & 17.2 & 16.9 \\
\hline Slovak Republic & 17.3 & 21.5 & 24.7 & 0.8 & 2.4 & 7.8 & 13.2 & 16.0 \\
\hline Slovenia & 28.5 & 33.1 & 38.8 & -2.4 & 9.9 & 18.9 & 23.1 & 30.3 \\
\hline Spain & 17.3 & 21.6 & 26.3 & 7.5 & 14.0 & 16.3 & 17.6 & 17.8 \\
\hline Sweden & 22.1 & 24.9 & 35.5 & 11.0 & 17.5 & 17.0 & 19.3 & 22.5 \\
\hline Switzerland & 28.8 & 29.2 & 31.6 & 16.4 & 24.2 & 23.7 & 25.0 & 29.4 \\
\hline Turkey $^{2}$ & 24.2 & 27.1 & 30.5 & 22.7 & 25.4 & 26.6 & 27.3 & 27.4 \\
\hline United Kingdom & 22.8 & 25.5 & 30.2 & 2.1 & 19.0 & 17.9 & 21.5 & 22.8 \\
\hline United States & 19.7 & 22.9 & 29.5 & -2.5 & 8.2 & 14.4 & 17.4 & 20.4 \\
\hline \multicolumn{9}{|l|}{ Unweighted average: } \\
\hline OECD & 21.6 & 25.6 & 31.2 & 3.9 & 14.1 & 16.6 & 19.7 & 22.4 \\
\hline EU-15 & 24.6 & 29.2 & 36.0 & 6.3 & 17.2 & 18.9 & 22.5 & 24.9 \\
\hline EU-21 & 24.1 & 28.3 & 34.2 & 4.9 & 15.0 & 17.5 & 21.2 & 24.4 \\
\hline
\end{tabular}

Note $:$ ch $=$ children.

1. Tw o-earner family.

2. Turkey w age figures are based on the old definition of average production w orker (Sector D in ISIC Rev.3). 
Table S.3. Marginal compulsory payment wedge

by family-type and wage level (as \% of augmented total labour costs), $2010^{1}$

\begin{tabular}{|c|c|c|c|c|c|c|c|c|}
\hline \multirow{3}{*}{ Family-type: } & \multirow{3}{*}{$\begin{array}{r}\text { single } \\
\text { no ch }\end{array}$} & \multirow{3}{*}{$\begin{array}{r}\text { single } \\
\text { no ch }\end{array}$} & \multirow{3}{*}{$\begin{array}{r}\text { single } \\
\text { no ch }\end{array}$} & \multirow[b]{2}{*}{ single } & & & & \\
\hline & & & & & married & married & married & married \\
\hline & & & & $2 \mathrm{ch}$ & $2 \mathrm{ch}$ & $2 \mathrm{ch}$ & $2 \mathrm{ch}$ & no ch \\
\hline Wage level ( $\%$ of AW): & $\begin{array}{l}67 \\
(1)\end{array}$ & $\begin{array}{r}100 \\
(2)\end{array}$ & $\begin{array}{r}167 \\
(3)\end{array}$ & $\begin{array}{l}67 \\
(4)\end{array}$ & $\begin{array}{r}100-0 \\
(5)\end{array}$ & $\begin{array}{r}100-33^{2} \\
(6)\end{array}$ & $\begin{array}{r}100-67^{2} \\
(7)\end{array}$ & $\begin{array}{r}100-33^{2} \\
(8)\end{array}$ \\
\hline Australia & 44.0 & 44.0 & 47.5 & 77.3 & 61.4 & 44.0 & 70.1 & 44.0 \\
\hline Austria & 56.3 & 59.9 & 41.4 & 56.3 & 59.9 & 59.9 & 59.9 & 59.9 \\
\hline Belgium & 66.3 & 66.3 & 69.4 & 66.3 & 66.3 & 66.3 & 66.3 & 66.3 \\
\hline Canada & 33.4 & 40.8 & 35.9 & 60.4 & 68.1 & 52.5 & 52.5 & 40.8 \\
\hline Chile & 22.8 & 22.8 & 26.6 & 22.8 & 22.8 & 22.8 & 22.8 & 22.8 \\
\hline Czech Republic & 48.6 & 48.6 & 48.6 & 55.7 & 54.0 & 54.0 & 54.0 & 48.6 \\
\hline Denmark & 40.9 & 42.3 & 56.1 & 40.9 & 42.3 & 42.3 & 42.3 & 42.3 \\
\hline Estonia & 42.9 & 42.9 & 42.9 & 42.9 & 42.9 & 42.9 & 42.9 & 42.9 \\
\hline Finland & 53.0 & 54.0 & 57.0 & 53.0 & 54.0 & 54.0 & 54.0 & 54.0 \\
\hline France & 63.2 & 52.0 & 59.7 & 57.7 & 49.1 & 49.1 & 52.0 & 52.0 \\
\hline Germany & 55.3 & 59.6 & 44.3 & 53.6 & 54.0 & 55.1 & 57.2 & 55.3 \\
\hline Greece & 34.4 & 46.2 & 51.5 & 34.4 & 50.1 & 50.1 & 50.1 & 50.1 \\
\hline Hungary & 52.2 & 52.2 & 67.0 & 52.2 & 52.2 & 52.2 & 52.2 & 52.2 \\
\hline Iceland & 50.7 & 50.7 & 50.7 & 57.3 & 57.3 & 57.3 & 54.8 & 50.7 \\
\hline Ireland & 36.8 & 55.8 & 55.8 & 67.5 & 36.8 & 36.8 & 36.8 & 36.8 \\
\hline Israel & 35.3 & 38.3 & 45.0 & 22.6 & 38.3 & 38.3 & 38.3 & 38.3 \\
\hline Italy & 56.0 & 56.1 & 63.6 & 56.5 & 57.0 & 57.0 & 56.6 & 56.1 \\
\hline Japan & 31.2 & 35.5 & 34.6 & 31.2 & 32.5 & 32.5 & 32.5 & 35.5 \\
\hline Korea & 19.4 & 28.4 & 22.6 & 18.2 & 24.7 & 24.7 & 24.7 & 28.4 \\
\hline Luxembourg & 41.8 & 53.1 & 53.1 & 39.3 & 36.9 & 40.1 & 46.6 & 40.1 \\
\hline Mexico & 25.6 & 26.7 & 35.5 & 25.6 & 26.7 & 26.7 & 26.7 & 26.7 \\
\hline Netherlands & 64.7 & 57.6 & 60.5 & 67.2 & 67.0 & 57.6 & 57.6 & 57.6 \\
\hline New Zealand & 19.2 & 32.3 & 35.5 & 19.2 & 39.2 & 39.2 & 39.2 & 32.3 \\
\hline Norway & 44.1 & 44.1 & 54.5 & 44.1 & 44.1 & 44.1 & 44.1 & 44.1 \\
\hline Poland & 41.2 & 41.2 & 41.2 & 33.7 & 33.7 & 41.2 & 41.2 & 41.2 \\
\hline Portugal & 47.5 & 47.5 & 56.3 & 47.5 & 39.1 & 47.5 & 47.5 & 47.5 \\
\hline Slovak Republic & 48.3 & 48.3 & 46.9 & 48.3 & 36.2 & 48.3 & 48.3 & 48.3 \\
\hline Slovenia & 43.6 & 51.0 & 60.4 & 32.9 & 43.6 & 43.6 & 43.6 & 51.0 \\
\hline Spain & 45.2 & 48.1 & 37.0 & 52.4 & 45.2 & 48.1 & 48.1 & 48.1 \\
\hline Sweden & 45.8 & 48.1 & 67.1 & 45.8 & 48.1 & 48.1 & 48.1 & 48.1 \\
\hline Switzerland & 37.9 & 40.9 & 47.1 & 33.4 & 37.0 & 39.3 & 41.6 & 39.3 \\
\hline Turkey $^{3}$ & 42.2 & 42.2 & 47.3 & 42.2 & 42.2 & 42.2 & 42.2 & 42.2 \\
\hline United Kingdom & 38.8 & 38.8 & 47.7 & 73.4 & 38.8 & 38.8 & 38.8 & 38.8 \\
\hline United States & 34.4 & 34.4 & 43.7 & 49.3 & 54.0 & 34.4 & 34.4 & 34.4 \\
\hline \multicolumn{9}{|l|}{ Unweighted average: } \\
\hline OECD & 42.9 & 45.6 & 48.6 & 46.4 & 45.7 & 45.0 & 46.1 & 44.6 \\
\hline EU-15 & 49.5 & 52.4 & 54.7 & 53.8 & 49.5 & 50.1 & 50.8 & 50.2 \\
\hline EU-21 & 48.6 & 50.9 & 53.7 & 51.1 & 47.9 & 49.2 & 49.7 & 49.4 \\
\hline
\end{tabular}

Note $:$ ch $=$ children.

1. Assumes a rise in gross earnings of the principal earner in the household. The outcome may differ if the wage of the spouse goes up, especially if partners are taxed individually.

2. Tw o-earner family.

3. Turkey wage figures are based on the old definition of average production w orker (Sector D in ISIC Rev.3). 
Figure S.2. Marginal compulsory payment wedge and marginal tax wedge for single taxpayers without children at average earnings, $2010^{1}$

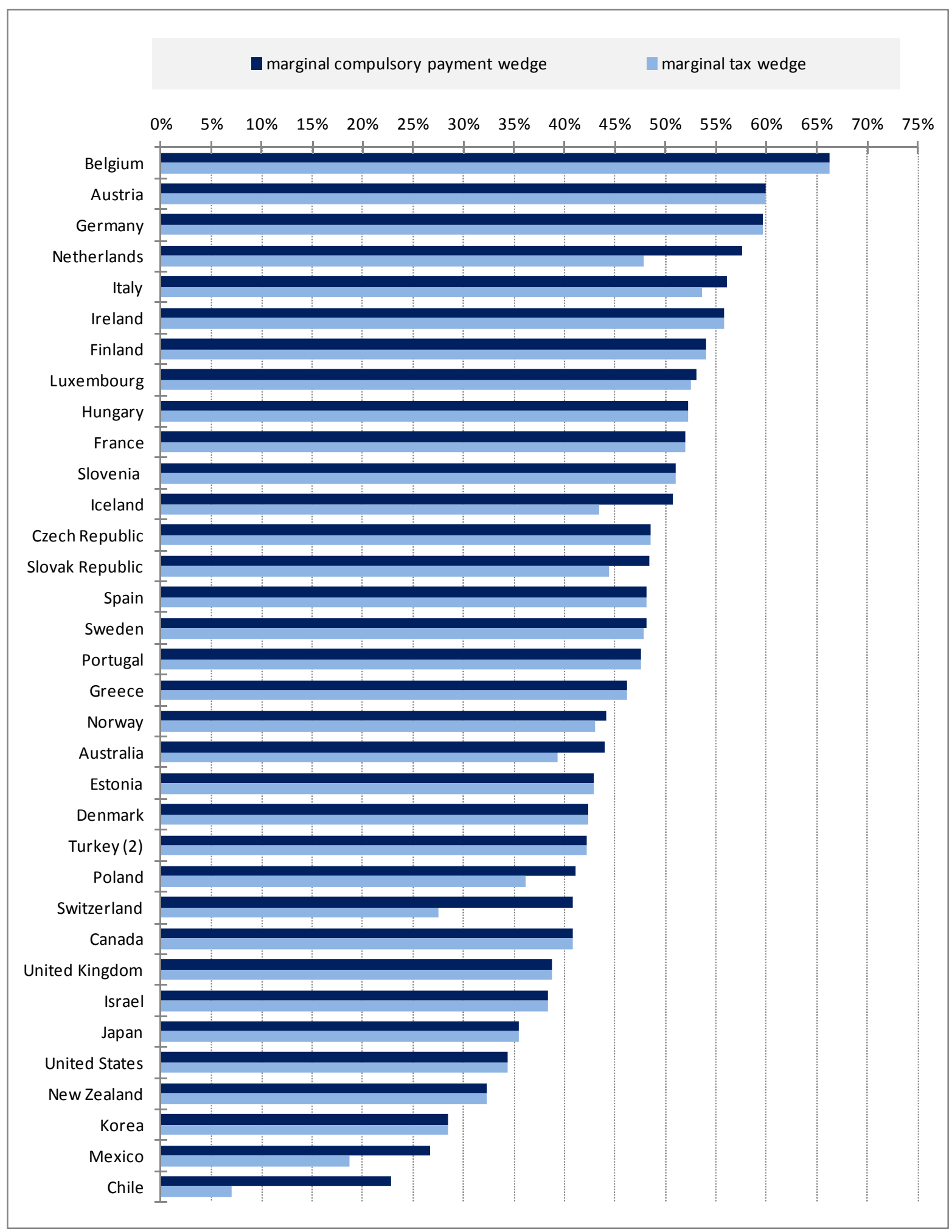

1. Countries are ranked by decreasing marginal compulsory payment wedge.

2. Turkey wage figures are based on the old definition of average production worker (Sector D in ISIC Rev.3). 
Table S.4. Marginal net personal compulsory payment rate

by family-type and wage level (as \% of gross wage earnings), $2010^{1}$

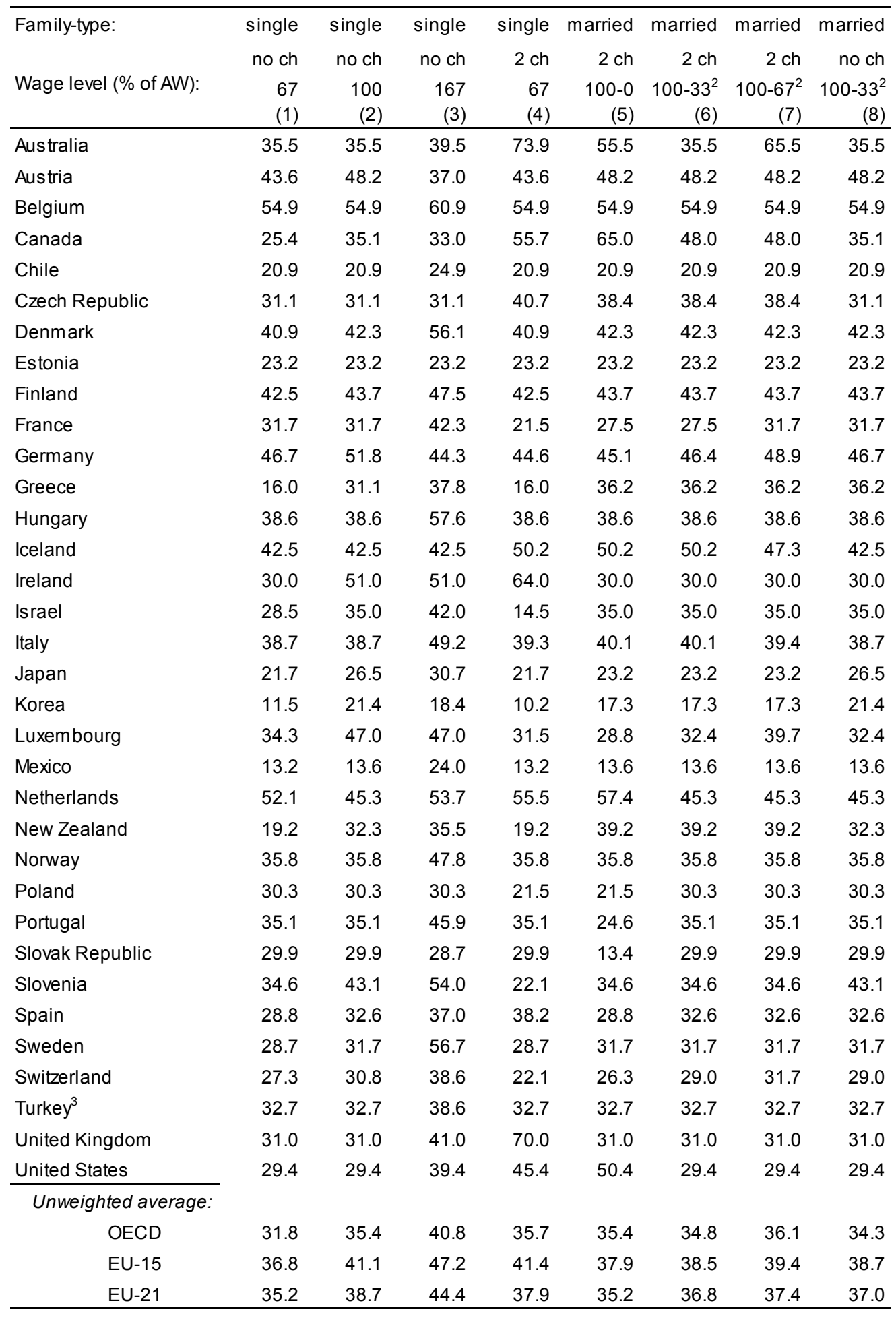

Note $:$ ch $=$ children.

1. Assumes a rise in gross earnings of the principal earner in the household. The outcome may differ

if the wage of the spouse goes up, especially if partners are taxed individually.

2. Tw o-earner family.

3. Turkey w age figures are based on the old definition of average production w orker (Sector D in ISIC Rev.3). 
Table S.5. Increase in total labour costs and reduction in net take-home pay as a result of non-tax compulsory payments paid by employers and employees

by family-type and wage level (in US dollars using PPP), 2010

\begin{tabular}{|c|c|c|c|c|c|c|c|c|}
\hline \multirow[t]{2}{*}{ Family-type: } & \multicolumn{2}{|c|}{ single } & \multicolumn{2}{|c|}{ single } & \multicolumn{2}{|c|}{ single } & \multicolumn{2}{|c|}{ single } \\
\hline & no ch & & no ch & & no ch & & $2 \mathrm{ch}$ & \\
\hline \multirow[t]{2}{*}{ Wage level $(\%$ of $A W)$ : } & \multicolumn{2}{|l|}{67} & \multicolumn{2}{|l|}{100} & \multicolumn{2}{|l|}{167} & \multicolumn{2}{|l|}{67} \\
\hline & $\begin{array}{r}\text { gross } \\
(1)\end{array}$ & $\begin{array}{r}\text { net } \\
(2) \\
\end{array}$ & $\begin{array}{r}\text { gross } \\
(3) \\
\end{array}$ & $\begin{array}{r}\text { net } \\
(4)\end{array}$ & $\begin{array}{r}\text { gross } \\
(5) \\
\end{array}$ & $\begin{array}{r}\text { net } \\
(6) \\
\end{array}$ & $\begin{array}{r}\text { gross } \\
(7) \\
\end{array}$ & $\begin{array}{r}\text { net } \\
(8) \\
\end{array}$ \\
\hline Australia & 2474 & 0 & 3711 & 0 & 6185 & 0 & 2474 & 0 \\
\hline Austria & 0 & 0 & $0^{\prime \prime}$ & $0^{7}$ & $0^{r}$ & $0^{7}$ & 0 & 0 \\
\hline Belgium & 0 & 0 & 0 & $0^{*}$ & $0^{r}$ & 0 & 0 & 0 \\
\hline Canada & 0 & 0 & $0^{\prime}$ & 0 & $0^{5}$ & $0^{\prime}$ & $0^{\prime \prime}$ & 0 \\
\hline Chile & $185^{\prime}$ & -1072 & $277^{\prime \prime}$ & $-1608^{\prime \prime}$ & $462^{\prime}$ & -2680 & $185^{\circ}$ & -1072 \\
\hline Czech Republic & 0 & 0 & 0 & 0 & 0 & 0 & 0 & 0 \\
\hline Denmark & $267^{\prime \prime}$ & $-88^{\prime}$ & $267^{\prime \prime}$ & $-88^{\circ}$ & $267^{r}$ & $-88^{\prime}$ & $267^{*}$ & -88 \\
\hline Estonia & 0 & 0 & 0 & 0 & $0^{r}$ & 0 & $0^{5}$ & 0 \\
\hline Finland & 0 & 0 & 0 & 0 & 0 & 0 & 0 & 0 \\
\hline France & 0 & 0 & $0^{5}$ & $0^{\circ}$ & $0^{5}$ & 0 & 0 & 0 \\
\hline Germany & $0^{r}$ & 0 & 0 & $0^{*}$ & $0^{*}$ & $0^{\prime \prime}$ & $0^{5}$ & 0 \\
\hline Greece & 0 & 0 & $0^{*}$ & $0^{*}$ & $0^{*}$ & $0^{*}$ & $0^{5}$ & 0 \\
\hline Hungary & 0 & 0 & 0 & $0^{*}$ & $0^{5}$ & 0 & 0 & 0 \\
\hline Iceland & $\quad 1731^{\circ}$ & $-866^{\top}$ & $2597^{F}$ & $-1299^{\circ}$ & $4329^{\circ}$ & $-2164^{\top}$ & $1731^{\circ}$ & -866 \\
\hline Ireland & 0 & 0 & $0^{F}$ & 0 & $0^{5}$ & 0 & 0 & 0 \\
\hline Israel & $1058^{\prime}$ & $-529^{\prime}$ & $1292^{\prime}$ & $-646^{\circ}$ & $1292^{\prime}$ & -646 & $1058^{\circ}$ & -529 \\
\hline Italy & 1770 & 0 & 2655 & 0 & $4426^{\prime}$ & 0 & $1770^{\circ}$ & 0 \\
\hline Japan & 0 & 0 & 0 & 0 & 0 & 0 & 0 & 0 \\
\hline Korea & 0 & 0 & 0 & $0^{\circ}$ & 0 & 0 & 0 & 0 \\
\hline Luxembourg & $486^{\circ}$ & -34 & $728^{\circ}$ & $-34^{\circ}$ & $1214^{\circ}$ & $-34^{\prime \prime}$ & $486^{\circ}$ & -34 \\
\hline Mexico & $744^{\circ}$ & $-82^{\prime}$ & $1116^{\circ}$ & $-124^{\circ}$ & $1860^{\prime}$ & $-206^{\prime}$ & $744^{\circ}$ & -82 \\
\hline Netherlands & 5792 & -1845 & $9105^{\circ}$ & $-2647^{\circ}$ & $15089^{\circ}$ & $-3916^{\prime \prime}$ & $5792^{\circ}$ & -1844 \\
\hline New Zealand & 0 & 0 & $0^{5}$ & 0 & $0^{\circ}$ & $0^{\prime \prime}$ & 0 & 0 \\
\hline Norway & $503^{\prime}$ & 0 & $836^{\prime \prime}$ & 0 & $1503^{\prime}$ & 0 & $503^{\circ}$ & 0 \\
\hline Poland & $488^{\circ}$ & -488 & $732^{\prime}$ & $-732^{\prime}$ & $1220^{\circ}$ & $-1220^{\prime}$ & $488^{\circ}$ & -488 \\
\hline Portugal & $0^{2}$ & 0 & 0 & $0^{\circ}$ & $0^{5}$ & $0^{5}$ & $0^{7}$ & 0 \\
\hline Slovak Republic & $1161^{\circ}$ & 0 & $1742^{\prime}$ & 0 & $2903^{\prime}$ & 0 & $1161^{\circ}$ & 0 \\
\hline Slovenia & 0 & 0 & 0 & 0 & 0 & 0 & 0 & 0 \\
\hline Spain & $0^{7}$ & 0 & $0^{*}$ & 0 & $0^{5}$ & 0 & $0^{7}$ & 0 \\
\hline Sweden & 0 & $-42^{\prime}$ & $0^{\prime}$ & $-71^{\circ}$ & $0^{\circ}$ & $-131^{F}$ & 0 & -42 \\
\hline Switzerland & 3662 & -5335 & 5494 & -6614 & 9156 & -9173 & 3662 & -6664 \\
\hline Turkey ${ }^{1}$ & 0 & 0 & 0 & 0 & 0 & 0 & 0 & 0 \\
\hline United Kingdom & $0^{\top}$ & 0 & 0 & 0 & 0 & 0 & 0 & 0 \\
\hline United States & $0^{r}$ & $0^{\top}$ & $0^{\prime}$ & 0 & $0^{r}$ & $0^{\prime}$ & $0^{2}$ & 0 \\
\hline Unweighted average & & & & & & & & \\
\hline OECD & $596^{\top}$ & $-307^{\top}$ & $889^{\prime}$ & $-402^{*}$ & $1450^{\circ}$ & $-586^{\prime}$ & $596^{\prime}$ & -346 \\
\hline EU-15 & $551^{\top}$ & $-137^{7}$ & $829^{\prime}$ & $-177^{\circ}$ & $1360^{\circ}$ & -256 & $551^{\circ}$ & -137 \\
\hline EU-21 & $472^{\top}$ & $-121^{\top}$ & $710^{*}$ & $-161^{*}$ & $1167^{\top}$ & $-241^{*}$ & $472^{\circ}$ & -121 \\
\hline
\end{tabular}

Note $:$ ch $=$ children.

1. Turkey wage figures are based on the old definition of average production w orker (Sector D in ISIC Rev.3). 
Table S.5 (cont'd). Increase in total labour costs and reduction in net take-home pay as a result of non-tax compulsory payments paid by employers and employees

by family-type and wage level (in US dollars using PPP), 2010

\begin{tabular}{|c|c|c|c|c|c|c|c|c|}
\hline Family-type: & \multicolumn{2}{|c|}{$\begin{array}{c}\text { married } \\
2 \mathrm{ch}\end{array}$} & \multicolumn{2}{|c|}{$\begin{array}{c}\text { married } \\
2 \mathrm{ch}\end{array}$} & \multicolumn{2}{|c|}{$\begin{array}{c}\text { married } \\
2 \mathrm{ch}\end{array}$} & \multicolumn{2}{|c|}{$\begin{array}{c}\text { married } \\
\text { no ch }\end{array}$} \\
\hline \multirow[t]{2}{*}{ Wage level (\% of AW): } & \multicolumn{2}{|l|}{$100-0$} & \multicolumn{2}{|c|}{$100-33^{1}$} & \multicolumn{2}{|c|}{$100-67^{1}$} & \multicolumn{2}{|c|}{$100-33^{1}$} \\
\hline & $\begin{array}{r}\text { gross } \\
(9) \\
\end{array}$ & $\begin{array}{r}\text { net } \\
(10) \\
\end{array}$ & $\begin{array}{r}\text { gross } \\
(11) \\
\end{array}$ & $\begin{array}{r}\text { net } \\
(12) \\
\end{array}$ & $\begin{array}{r}\text { gross } \\
(13) \\
\end{array}$ & $\begin{array}{r}\text { net } \\
(14) \\
\end{array}$ & $\begin{array}{r}\text { gross } \\
(15) \\
\end{array}$ & $\begin{array}{r}\text { net } \\
(16) \\
\end{array}$ \\
\hline Australia & 3711 & 0 & 4948 & 0 & 6185 & 0 & 4948 & 0 \\
\hline Austria & $0^{7}$ & $0^{\prime \prime}$ & 0 & $0^{\prime}$ & $0^{7}$ & $0^{\prime}$ & $0^{7}$ & 0 \\
\hline Belgium & $0^{7}$ & 0 & $0^{7}$ & $0^{r}$ & 0 & $0^{5}$ & $0^{r}$ & 0 \\
\hline Canada & 0 & $0 "$ & $0^{\prime}$ & 0 & 0 & 0 & 0 & 0 \\
\hline Chile & $277^{\circ}$ & $-1608^{\prime}$ & $370^{\prime}$ & $-2144^{\top}$ & $462^{\circ}$ & $-2680^{\top}$ & $370^{\prime}$ & -2144 \\
\hline Czech Republic & $0^{\circ}$ & $0^{\prime}$ & $0^{\prime}$ & $0^{\top}$ & $0^{\top}$ & $0^{\top}$ & 0 & 0 \\
\hline Denmark & $267^{\circ}$ & $-88^{\prime}$ & $533^{\nabla}$ & $-177^{\prime}$ & $533^{\prime}$ & $-177^{\top}$ & $533^{\prime}$ & -177 \\
\hline Estonia & $0^{*}$ & 0 & 0 & $0^{\prime}$ & $0^{\prime}$ & $0^{\prime}$ & $0^{\prime \prime}$ & 0 \\
\hline Finland & 0 & $0^{\prime \prime}$ & 0 & $0^{*}$ & 0 & $0^{5}$ & 0 & 0 \\
\hline France & $0^{7}$ & $0^{*}$ & 0 & 0 & 0 & $0^{7}$ & $0^{\prime}$ & 0 \\
\hline Germany & 0 & 0 & 0 & $0^{5}$ & $0^{\prime}$ & $0^{5}$ & $0^{\prime \prime}$ & 0 \\
\hline Greece & $0^{*}$ & $0^{7}$ & $0^{7}$ & $0^{\top}$ & $0^{\prime}$ & $0^{2}$ & 0 & 0 \\
\hline Hungary & $0^{*}$ & 0 & 0 & $0^{5}$ & 0 & $0^{5}$ & 0 & 0 \\
\hline Iceland & $2597^{7}$ & $-1299^{\circ}$ & $3463^{F}$ & $-1731^{\top}$ & $4329^{\circ}$ & $-2164^{\top}$ & $3463^{r}$ & -1731 \\
\hline Ireland & 0 & 0 & 0 & 0 & 0 & 0 & 0 & 0 \\
\hline Israel & $1292^{\circ}$ & $-646^{\prime}$ & $1821^{\circ}$ & $-911^{\top}$ & $2350^{\circ}$ & $-1175^{\top}$ & $1821^{\circ}$ & -911 \\
\hline Italy & $2655^{\circ}$ & 0 & $3540^{\circ}$ & $0^{5}$ & $4426^{\circ}$ & $0^{5}$ & $3540^{\prime \prime}$ & 0 \\
\hline Japan & 0 & 0 & 0 & 0 & 0 & 0 & 0 & 0 \\
\hline Korea & 0 & 0 & 0 & 0 & 0 & $0^{5}$ & 0 & 0 \\
\hline Luxembourg & $728^{\circ}$ & $-34^{F}$ & $971^{\circ}$ & $-68^{r}$ & $1214^{\top}$ & $-68^{2}$ & $971^{\top}$ & -68 \\
\hline Mexico & $1116^{\circ}$ & $-124^{*}$ & $1488^{\circ}$ & $-165^{\prime}$ & $1860^{\circ}$ & $-206^{\top}$ & $1488^{\circ}$ & -165 \\
\hline Netherlands & $9105^{\circ}$ & $-3684^{\top}$ & $10715^{r}$ & $-4025^{r}$ & $14898^{\circ}$ & $-4660^{\top}$ & $10715^{F}$ & -4025 \\
\hline New Zealand & 0 & 0 & 0 & 0 & 0 & 0 & 0 & 0 \\
\hline Norway & $836^{\circ}$ & 0 & $1006^{\circ}$ & $0^{\top}$ & $1339^{\circ}$ & 0 & $1006^{\prime}$ & 0 \\
\hline Poland & $732^{\circ}$ & -732 & $976^{\circ}$ & $-976^{\prime}$ & $1220^{\circ}$ & $-1220^{\circ}$ & 976 & -976 \\
\hline Portugal & $0^{\circ}$ & 0 & 0 & 0 & 0 & $0^{*}$ & 0 & 0 \\
\hline Slovak Republic & $1742^{\circ}$ & 0 & $2322^{\prime}$ & $0^{5}$ & $2903^{\circ}$ & 0 & $2322^{F}$ & 0 \\
\hline Slovenia & $0^{*}$ & $0^{\prime \prime}$ & $0^{F}$ & $0^{\top}$ & $0^{\prime}$ & $0^{5}$ & 0 & 0 \\
\hline Spain & $0^{r}$ & $0^{F}$ & 0 & 0 & 0 & $0^{5}$ & 0 & 0 \\
\hline Sweden & $0^{\prime}$ & $-71^{\prime \prime}$ & 0 & $-85^{\prime}$ & $0^{\prime}$ & $-112^{\top}$ & 0 & -85 \\
\hline Switzerland & $5494^{\circ}$ & $-10720^{\prime}$ & $7325^{\circ}$ & $-11999^{\prime}$ & $9156^{\top}$ & $-13278^{\circ}$ & $7325^{\prime}$ & -10670 \\
\hline Turkey $^{2}$ & $0^{\circ}$ & 0 & 0 & 0 & 0 & 0 & 0 & 0 \\
\hline United Kingdom & 0 & 0 & 0 & 0 & 0 & 0 & 0 & 0 \\
\hline United States & $0^{\prime}$ & $0^{\prime}$ & $0^{7}$ & $0^{\top}$ & $0^{7}$ & $0^{7}$ & 0 & 0 \\
\hline Unweighted aver & & & & & & & & \\
\hline OECD & $889^{\circ}$ & -553 & 1225 & -648 & 1556 & -748 & 1225 & -609 \\
\hline EU-15 & $829^{\circ}$ & -246 & 1196 & -274 & 1540 & -314 & 1196 & -274 \\
\hline EU-21 & $710^{\circ}$ & $-211^{\circ}$ & $1011^{F}$ & $-242^{\top}$ & $1296^{\circ}$ & $-282^{\top}$ & $1011^{\top}$ & -242 \\
\hline
\end{tabular}

Note $:$ ch $=$ children.

1. Tw o-earner family.

2. Turkey wage figures are based on the old definition of average production w orker (Sector D in ISIC Rev.3). 
Table S.6: non-tax compulsory payments in OECD countries in 2010 (1) (2)

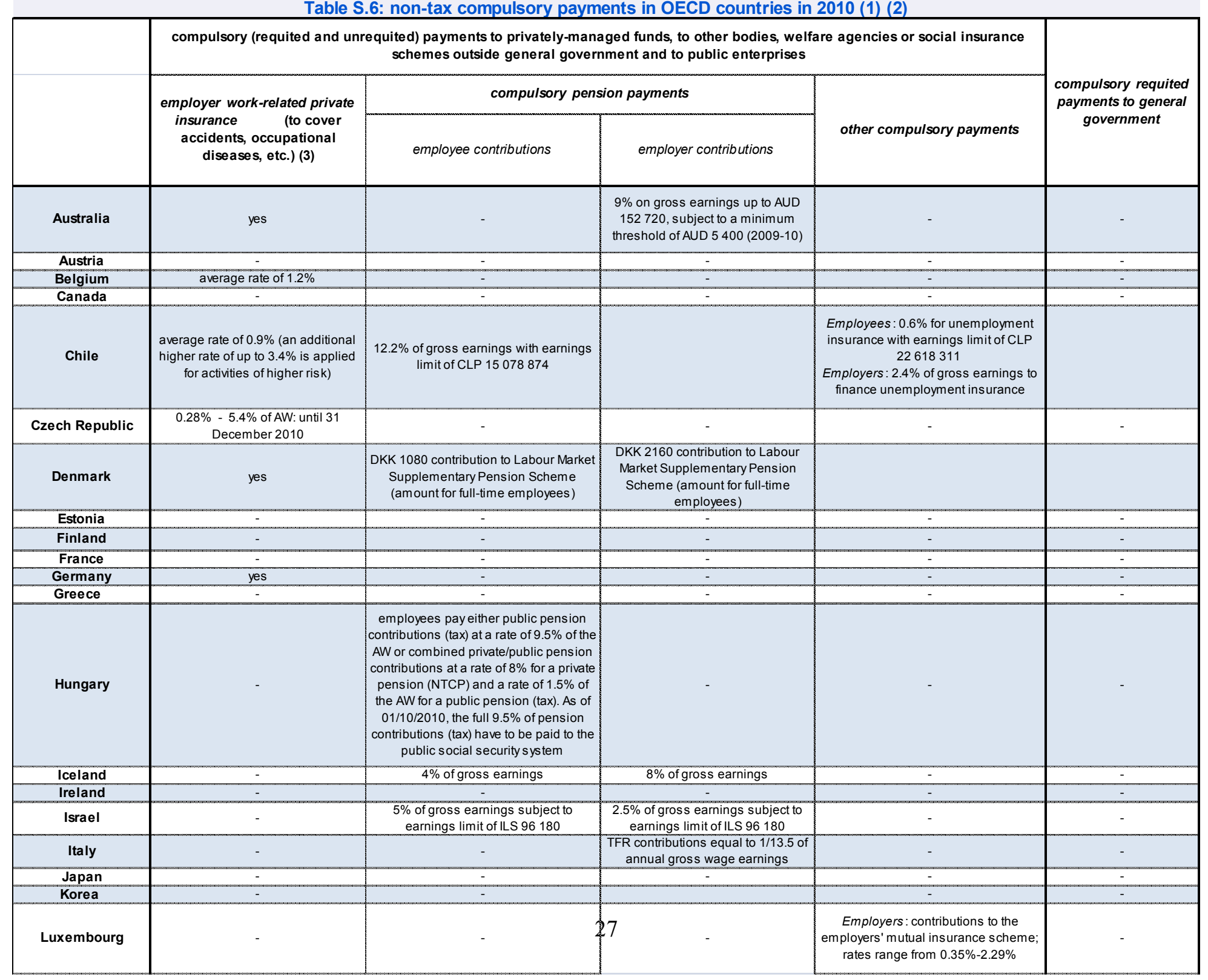




\begin{tabular}{|c|c|c|c|c|c|}
\hline \multirow{2}{*}{ Mexico } & \multirow{2}{*}{ - } & \multirow{2}{*}{ - } & \multirow{2}{*}{$\begin{array}{l}2.0 \% \text { of AW (earnings ceiling that } \\
\text { applies to all contributions } \\
\text { separately: } 25 \text { times minimum wage } \\
\text { in Mexico City, which in } 2010 \text { is MXN } \\
524323 \text { ) }\end{array}$} & $\begin{array}{l}\text { Employees: } 1.125 \% \text { of AW for } \\
\text { discharge and old age insurance }\end{array}$ & - \\
\hline & & & & $\begin{array}{c}\text { Employers: } 3.15 \% \text { of AW for discharge } \\
\text { and old age insurance }+5.0 \% \text { for } \\
\text { housing fund INFONAVIT }\end{array}$ & - \\
\hline \multirow{2}{*}{ Netherlands } & \multirow{2}{*}{ - } & \multirow{2}{*}{$\begin{array}{l}\text { on average } 3.76 \% \text { of gross earnings net } \\
\text { of the pension franchise of EUR } 12952\end{array}$} & \multirow{2}{*}{$\begin{array}{l}\text { 17.10\% on gross earnings } \\
\text { exceeding EUR } 12952\end{array}$} & $\begin{array}{c}\text { Employees: health insurance premium } \\
\text { of EUR 1 064; employees possibly } \\
\text { receive a corresponding health care } \\
\text { benefit }\end{array}$ & \multirow{2}{*}{ - } \\
\hline & & & & $\begin{array}{c}\text { Employers: health contribution at a rate } \\
\text { of } 6.9 \% \text { up to maximum of net earnings } \\
\text { of EUR } 32369\end{array}$ & \\
\hline New Zealand & $\begin{array}{l}\text { average employer rate } 1.26 \% \text { levied } \\
\text { on "liable payroll" }\end{array}$ & - & - & $\begin{array}{c}\text { Employees : } 1.244 \% \text { of AW for no-fault } \\
\text { personal (non-work related) injury } \\
\text { insurance }\end{array}$ & - \\
\hline Norway & - & - & $\begin{array}{l}2.0 \% \text { of AW for earnings between } \\
\text { NOK } 74721 \text { and NOK } 896652\end{array}$ & - & - \\
\hline Poland & yes & $3.65 \%$ of average earnings & $3.65 \%$ of average earnings & - & - \\
\hline Portugal & yes & - & - & - & - \\
\hline Slovak Republic & - & - & $\begin{array}{l}\text { 9.0\% of AW; earnings ceiling: EUR } \\
33402\end{array}$ & \begin{tabular}{|} 
Employers: contribution to Social \\
Funds; rate ranges from $0.6 \%-1 \%$ of \\
all gross wages payable
\end{tabular} & - \\
\hline Slovenia & - & - & - & - & - \\
\hline Spain & $\begin{array}{c}1 \%-8.15 \% \text { of AW for gross earnings } \\
\text { between EUR } 8398.48 \text { and EUR } 36 \\
889.2 \text { to either public or private firm } \\
\text { (2008 information) }\end{array}$ & - & - & - & - \\
\hline Sweden & - & - & - & $\begin{array}{c}\text { Employees: burial fee of } 0.22 \% \text { on top } \\
\text { of the local tax rate to the Chuch of } \\
\text { Sweden }\end{array}$ & - \\
\hline \multirow[t]{2}{*}{ Switzerland } & \multirow{2}{*}{$\begin{array}{l}\text { yes: both employees and employers } \\
\text { have to pay a certain percentage of } \\
\text { gross earnings; in 2008, the } \\
\text { estimated representative rates were } \\
\text { respectively } 1.56 \% \text { and } 0.89 \%\end{array}$} & \multirow{2}{*}{$\begin{array}{c}7.65 \% \text { of gross earnings (repres entative } \\
\text { rate) }\end{array}$} & \multirow{2}{*}{$\begin{array}{l}9.75 \% \text { of gross earnings } \\
\text { (representative rate) }\end{array}$} & $\begin{array}{l}\text { Employees: health insurance } \\
\text { contribution of CHF } 4213.2 \text { for each } \\
\text { adult and CHF } 1008 \text { for each child } \\
\text { (representative amounts) }\end{array}$ & - \\
\hline & & & & \begin{tabular}{|c|} 
Employers: family allowance \\
contribution of $1.2 \%$ of gross earnings \\
(repres entative rate)
\end{tabular} & \\
\hline Turkey & - & - & - & - & - \\
\hline United Kingdom & - & - & - & - & - \\
\hline United States & ves & - & - & - & - \\
\hline
\end{tabular}

(1) The table shows information for the 2010 fiscal year except when indicated otherwise.

(2) Non-tax compulsory payments that are not generally applicable to taxpayers within at least one family type included in the Taxing Wages Report are NOT included in the table. However, the table does show the NTCPs that are generally applicable but for which no representative rate can be included as, for instance, accident insurance contributions. This table therefore contains information on all NTCPs, including the NTCPs that have not been included in the compulsory payments calculations.

(3) accident insurance premiums are not included in the calculations underlying the compulsory payments indicators because no representative rate could be calculated in most countries. 


\section{BIBLIOGRAPHY}

OECD, 2006, Fundamental Reform of Personal Income Tax, OECD Tax Policy Studies, No. 13. OECD, 2010, Revenue Statistics 1965-2009.

OECD, 2011, Taxing Wages 2009-2010. 


\section{OECD TAXATION WORKING PAPERS}

No. $1 \quad$ Tax reform trends in OECD countries

Bert Brys, Stephen Matthews and Jeffrey Owens

No. $2 \quad$ What is a competitive tax system?

Stephen Matthews

No. 3 Making fundamental tax reform happen

Bert Brys

No. $4 \quad$ Trends in top incomes and income inequality and the implications for tax policy

Stephen Matthews

No. 5 The evaluation of the effectiveness of tax expenditures: a novel approach. An application to the regional tax incentives for business investments in Italy

Antonella Caiumi

No. $6 \quad$ Corporate taxation and SMEs: the Italian experience

Marco Manzo

No. 7 Consumption taxation as an additional burden on labour income

Fidel Picos-Sánchez

No. $8 \quad$ Non-tax compulsory payments as an additional burden on labour income Bert Brys

No. 9 Taxation and innovation Pamela Palazzi

No. 10 Wage income tax reforms and changes in tax burdens: 2000-2009 Bert Brys

No. 11 Shifting from social security contributions to consumption taxes: the impact on low-income earner work incentives

Alastair Thomas and Fidel Picos-Sánchez 


\section{THE OECD TAXATION WORKING PAPERS SERIES ON LINE}

The OECD Taxation Working Papers Series may be found at:

- The OECD Centre for Tax Policy and Administration website: www.oecd.org/ctp/workingpapers

- The OECD's online iLibrary: http://www.oecd-ilibrary.org/

- The Research Papers in Economics (RePEc) website: www.repec.org

For further information on the OECD Taxation Working Papers Series, please write to: ctp.contact@oecd.org. 